\title{
The Relationship between Faculty Members' Job Satisfaction and Perceptions of Organizational Politics
}

\author{
Mehmet DURNALI* \\ Zonguldak Bülent Ecevit University, Ereğli Faculty of Education, Zonguldak, Turkey
}

\begin{tabular}{|c|c|}
\hline & $\begin{array}{l}\text { P1nar AYYILDIZ } \\
\text { Inkara Medipol University, Ankara, Turkey }\end{array}$ \\
\hline Article history & \multirow{6}{*}{$\begin{array}{l}\text { This study aimed to investigate not only the level of faculty members' } \\
\text { views on job satisfaction and their perceptions of organizational politics } \\
\text { but also the relationship between their job satisfaction and perceptions of } \\
\text { organizational politics. The study intended to examine how well faculty } \\
\text { members' job satisfaction can predict the perceptions of organizational } \\
\text { politics as well. The descriptive relational survey model dominated the } \\
\text { research. The study group consisted of } 240 \text { faculty members who work } \\
\text { for } 7 \text { state and } 7 \text { private universities located in Ankara city. Data were } \\
\text { collected using the Job Satisfaction Scale for Academicians (JSSA), and } \\
\text { Perceptions of Organizational Politics Scale (POPS) Questionnaire along } \\
\text { with a demographic information form developed by the researchers. Data } \\
\text { were collected in September and October in } 2019 \text {. Descriptive statistic } \\
\text { (mean, standard deviation), reliability (Cronbach's Alpha coefficient), } \\
\text { correlation (Pearson coefficient) and Multiple Linear Regression were } \\
\text { used to analyze the data. SPSS v. } 23 \text { was referred to in doing so. The } \\
\text { main findings indicated that the faculty members' job satisfaction total } \\
\text { and nature of the job sub-dimension scores were at a very high level } \\
\text { while organizational policy sub-dimension scores were high. Faculty } \\
\text { members' scores on "Go along to get ahead" were the highest and they } \\
\text { appeared uncertain about "General political behavior" and "Honesty / } \\
\text { Work ethics". The JSSA subscales were moderately and positively } \\
\text { correlated with the POPS subscales. The regression result demonstrated } \\
\text { that the JSSA's intrinsic and extrinsic job satisfaction dimensions } \\
\text { significantly and positively predicted the POPS subscales. }\end{array}$} \\
\hline $\begin{array}{l}\text { Received: } \\
12.10 .2019\end{array}$ & \\
\hline $\begin{array}{l}\text { Received in revised form: } \\
26.11 .2019\end{array}$ & \\
\hline $\begin{array}{l}\text { Accepted: } \\
27.11 .2019\end{array}$ & \\
\hline Key words: & \\
\hline $\begin{array}{l}\text { Job satisfaction; organizational } \\
\text { behavior; organizational } \\
\text { politics; faculty members; } \\
\text { higher education } \\
\text { administration }\end{array}$ & \\
\hline
\end{tabular}

\section{Introduction}

It goes without saying that the successful operation of any institution is subject to countless factors pertaining to inside and outside sources as well as to those linked to all the related/assumed shareholders. Some of these (f)actors cannot easily be detected in a proactive fashion or cannot even be recognized at ease. Yet it would be fair to state that one of these influencers which plays a highly active role in terms of the general motivation of employeesperhaps the group consisting the main stakeholders as has been mentioned by Swamy, Nanjundeswaraswamy and Rashmi (2015) - is their 'job satisfaction'. In its simplest sense, the 
very term refers to the negative or positive feelings of workers towards their own job viz.,- what they do as part of their job. In certain resources, it is defined as admiration and contentment one feels to their job (Başar \& Basım, 2015) and also as their overall attitude to it (Usop, Kadtong, \& Usop, 2013). It is reported that job satisfaction and employee satisfaction are at times alternately used words (Küskü, 2001) and one of the more recent attempts to define job satisfaction is describing it as positive worker morale (Heathfield, 2016). Ravari BazarganHejazi, Ebadi, Mirzaei and Oshvandi (2012) compiled the representations of the conception of job satisfaction checking the bulk of literature and shared that it as a multi-faceted jargon which is pertinent to affect, expectations, and belief systems of workers.

In fact, determining job satisfaction of employees is crucial since their willingness and hence their performance (Gül, Oktay, \& Gökçe, 2008) is closely connected to the levels of job satisfaction they possess. To that end, it is not surprising at all to witness in various studies (e.g. Lin, 2012) that job satisfaction is emphasized as a major facilitator of productivity and efficiency. What is more, job satisfaction is usually associated with some other key notions of the field like loyalty (Witt \& Beokermen, 1991), organizational citizenship (Swaminathan \& Jawahar, 2013), employee engagement (Lu, Lu, Gursoy, \& Neale, 2016) in the workplace whereas with others of negative nature such as psychological distress (Moen, Kelly, \& Lam, 2013), burnout, absenteeism (Tschopp, Grote, \& Gerber, 2014) that leads to turnover (A1 Rubaish, Rahim, Abumadini, \& Wosornu, 2016) and thusly making the adverse effects of the phenomenon often times difficult to prevent (Altuntaş, 2014). It is notable that employees' job satisfaction is fundamental for their not leaving the job (Alqashan, 2013; Çekmecelioğlu, 2006; İnan \& Çelik, 2018; Özel, 2014; Özyer, 2010; Randhawa, 2007). In brief, job satisfaction is the worker's basic stance taken towards their job (Weiss, 2002).

Though job satisfaction is thought to be studied first by Hoppock (1935), the idea emerged with Taylorizm via "Scientific Management" understanding of the 1900s. It is worth underlining on this timeline that Herzberg's Two-Factor Theory (1959) is a milestone in that it sets forth a twodimensional novel model of worker motivation:

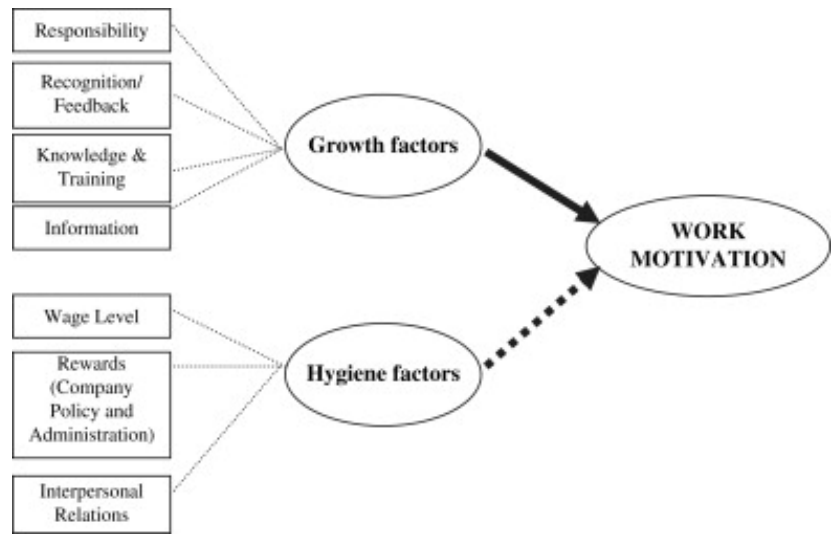

Figure 1. Herzberg's Two-Factor Theory (Lundberg, Gudmundson, \& Andersson, 2009)

In this model Herzberg (1966) argued that factors of job satisfaction are not the same as the ones resulting in job dissatisfaction. The motivation-hygiene theory comes into play here to further clarify the situation. "Hygiene factors" are considered maintenance factors that are vital to refrain from dissatisfaction, but they do not warranty satisfaction on their own. There indeed are other Content and Process Theories apart from this model of Herzberg, some of which are Maslow's Need Hierarchy Theory and Vroom's Expectancy Theory (Haque, Haque, \& Islam, 
2014); Aldefer-ERG (Caulton, 2012); McClelland's Need Theory (Talaue, 2016) Locke's Goal-Setting Theory (Locke \& Latham, 2002); Adams' Equity Theory (Huseman, Hatfield, \& Miles, 1987) and Job Characteristic Theory (Hackman \& Oldham, 1976) to name a few.

The concept then began to be dealt with through the following two aspects in particular in the second half of 1970s (Farrell, 1978; Seashore \& Teber, 1975) as: personal aspects (demographic features of the workers, their personal qualities, skills, contextual, perceptual, cognitive, and expectation) together with the rather environmental and/or job-bound ones (political/economic context, professional nature, organizational climate, and ethos) alongside the fact that it was handled through the 'relation between' these two aforementioned groups of variables (McClelland, 1976). During these years Hackman and Oldman (1975) formed a model of occupation contentment and Salancik and Pfeffer (1978) stated that job satisfaction is actually relational and relative in that workers have an idea of their job satisfaction levels comparing those with others'. It is pinpointed that Locke's Range of Affect Theory (1976) of those years stands out amongst others being a well-known model of this sort. Job satisfaction as an area of study has always attracted more and more attention of researchers since then i.e. from the beginning of 1980s (Gautam, Mandal, \& Dalal, 2006). Recently two paradigms seemed to have come into view: taking job satisfaction as affective employee satisfaction and the other one is seeing it as cognitive employee satisfaction where the former is a more general emotional response to a job and the latter is the evaluation of circumstances, chances or gains (Thompson \& Phua, 2012) applying to the job.

Studies of job satisfaction have been conducted for decades using a fair number of instruments, for instance, there have been global/cross-national scales, multidimensional instruments, single-item and multiple-item tools intending to assess levels of job satisfaction of workforce in general or specified places (Van Saane, Sluiter, Verbeek, \& Frings-Dresen, 2003). With a view to identifying job satisfaction levels of workers, several tools have been developed by scholars so far some of which can be listed as: Minnesota Satisfaction Questionnaire (MSQ) by Weiss, Dawis, England and Lofquist (1967); Bell and Weaver's (1983); Lester's (1987); Hellriegel and Woodman's (1995) Job Descriptive Index (JDI); Jiménez's (2008). Besides these, Ali and Akhter (2009) came up with a questionnaire so as to interpret the job satisfaction levels of academics working for a private university in Bangladesh. Lepold, Tanzer, Bregenzer and Jiménez (2018) also investigated Facet-Items vs. Facet Scales of job satisfaction. It is significant to underscore here that demographic factors affect job satisfaction levels to a great extent (Reddy, Reddy, \& Rao, 2016) making them an integral part of any form of measurement carrying alternative orientations and structures of different kind.

It is acknowledged that relatively fewer studies in the literature are encountered particularly belonging to the job satisfaction levels of faculty or academics (Ahsan, Abdullah, Fie, \& Syed Shah Alam, 2009; Aslan, Shaukat, Ahmed, Shah, \& Mahfar, 2014) as opposed to a great deal of research concentrating on job satisfaction within the framework of diverse disciplines e.g. Business, Health Sciences, Psychology in different work places (Strydom, 2011) including schools (Hawley, 2008; Mehta, 2012; Nir, 2012; Kumari, \& Jafri, 2011; Seniwoliba, 2013). A lack of theoretical negotiation upon the potential constructs of job satisfaction was voiced and it was uttered that there are 'dozens' of dimensions of loads of instruments/tools in the research field (Pepe, Addimando, \& Veronese, 2017). Notwithstanding, it is underlined that the issue is still worth analyzing (Sidık, Ab Hamid, Ibrahim, \& Ali, 2017) for researchers especially on the part of university employees whose job satisfaction is compatible both with academic success of learners (Banerjee \& Lamb, 2016) and with the overall improvement of the university that they work at. Job satisfaction of academics is again akin to carrying the services and quality of 
the organization, which is the university or the higher education institution in that case, to desired levels (Machado-Taylor, Meira Soares, Ferreira, \& Gouveia, 2011). This quality improvement in return, at macro levels, is essential for the improvement of the country bearing in mind the roles and functions of higher education institutions regarding employment, innovation and scientific research. Having said that, it is of crucial importance to touch upon and reiterate the inherent components of job satisfaction namely salary, relationship between colleagues, job security and many others when it comes to studying the topic within the sphere of academic organizations (Khalid, 2012). In spite of being limited, the studies on universities and university workers conducted in varying socio-cultural backgrounds (Bernard, 2012; Dave \& Ravel, 2014; Ghaffar, Ameer, Arshad, \& Urooj, 2013; Toker, 2009) still offer shifting views at the same time adding onto the existing literature. In light of all these, it could be said with confidence that there is a gap in the available literature in regard to studies researching job satisfaction levels of academicians.

Political games in an institution are exposed to outside forces of culture, politics and economy where one set of games are known as 'insurgency games', and the others are entitled 'counterinsurgency games' (Mintzberg, 1985). One can easily think that any organization / institution / workplace is political in an ingrained way-discounting if it is an ethical or objective conceptand this realm has reflections in the literature (e.g. Ferris \& Hochwarter, 2010). Yet, in an ironic manner, it is interlineated in the literature itself that organizational politics as an issue still remains almost 'untouched' (Heath \& Sitkin, 2001) even by the onset of the new millennium taking into account the huge area of study constituting a great potential for researchers of the field. Evidence displays that the area is empirically tested in a single cultural context (North America), failing to take into consideration the probable social differences (Poon, 2003; Zibenberg, 2017) which are highly critical for scholars to check what the subject would be telling about various workplaces containing different workers, belief systems and rituals as a whole. This is essential thinking that perceptions of organizational politics may shift from one individual to another (Bodla \& Danish, 2009). Also it is shared that possible positive results of organizational politics like advancing in career, gaining prestige/status, increased power/position, reaching both personal and organizational aims, accomplishing a task/feelings of achievement, ego (Vigoda-Gadot \& Kapun, 2005) and so on are inclined to be neglected with some exceptions (e.g. Cacciattolo 2015; Drory \& Vigoda-Gadot, 2010; Gotsis \& Kortezi, 2010; Othman, 2008; Vredenburgh \& Shea-VanFossen, 2010) since the rest of the studies mostly figured out the negative aspects (Başar \& Varoğlu, 2016; Eldor, 2017; Rosen \& Hochwarter, 2014), which again leads to a restricted comprehension of an arguably exhaustive political phenomena (Ferris \& Hochwarter, 2012).

Organizational politics is primarily defined as exercising power/influence that tends to arise out of the processes or procedures of the institution (Kurchner-Hawkins \& Miller, 2006; Miller, Rutherford, \& Kolodinsky, 2008) resulting from and in a shadowy system of illegitimate behaviors (Stacey, 1996) thus and so is made up of informal or unofficial attitude and behavior (Aryee, Chen, \& Budhwar, 2004; Ulkeryildiz, 2009) such as employees' not contacting the immediate head(s) during times of conflict as expected but approaching other seniors (Gotsis $\&$ Kortezi, 2010). In institutions or workplaces the following political acts are usually faced: individual ones, coalition ones and lastly network levels (Kinicki, 2008). Byrne, Manning, Weston and Hochwarter (2017) and Searle and Auton (2015) indicated that challenge and organizational politics are closely interrelated. Doldor (2007) announced that terminology like political climate, political behaviors, political tactics, political skills, influence tactics and political influence behavior in an organization can be used interchangeably. Similar to the previously inspected concept of this paper: job satisfaction; organizational politics is another 
term linked to certain organizational jargon like stress, staff turnover, Organizational Citizenship Behavior (OCB) as well as productivity (Miller et al., 2008). It is seen in many of these discussions that there are references to the term job satisfaction too, which shows that these two terms are both worth studying, preferably together to explore whether there exists any co-relation between them in differing socio-cultural contexts i.e. in various countries like Turkey and in different organizations such as universities.

Organizational politics carries importance both for the employees and the managers since the first group seems to be constantly checking if the workplace is a political arena which calls for responding to relevant dynamics successfully (Buchanan, 2008) and the second group frequently tries to maintain the balance of 'doing things as necessary'. Hoy and Miskel's (2008) political tactics: ingratiating, networking, information management, impression management and coalition building ones (2008) elaborate on the topic with-yet-another perspective. Withal Zanzi and O'Neil (2001) remarked sanctioned political tactics and non-sanctioned political tactics within the context of organizational politics and there are Sussman, Winkler, Huotilainen, Ritter and Näätänen's (2002) tactics which are attacking/blaming other workers, making use of information as a political tool, developing and sustaining a favorable image, coming up with a base of support, ingratiation, ensuring allies and forming power coalitions, creating obligations and reciprocity. Kylén (1999) discovered that political tactics of reactive type of workers are linked to laissez-faire leadership style and groups whose leaders are more decisive and caring often demonstrate less reactive political/tactical behaviors. Such outcomes originate some questions as to whether organizational politics would cause inequality among the workers making the concept more complicated-if not totally 'knotty'.

Kacmar and Ferris (1991) introduced such indicators of organizational politics: variables that are organizational factors (centralization, hierarchy, formalization, span of control), variables related to job factors (autonomy, job control, feedback channels and procedure, chances of promotion, variety in skills), variables which are individual-bound factors (age, sex, Machiavellianism, self-monitor). Later, Kacmar and Carlson's (1997) Perceptions of Organizational Politics Scale set the tone in the relevant literature as it was designated with the intention to measure the concept delving originally into numerous other conceptions through scales: faith in people, alienation, cynicism, altruism, trust, social attitude and self-activity inventory owning the dimensions of "General political behaviors", "Go along to get ahead", "Coworkers", "Self-serving behaviors" and "Pay and promotions". The relevant research aimed at pondering the antecedents, moderators, results of organizational politics (e.g. Randall, Cropanzano, Bormann, \& Birjulin, 1999; Valle \& Witt, 2001). In time the concept, whose holistic picture is provided below, developed further. It is also remarkable that as Valle and Perrewe (2000) claimed researchers tend to pore over perceptions of politics in organizations rather than actual political behavior. The visual below represents organizational politics situating it in a central position towards some other related terms and concepts in the field.

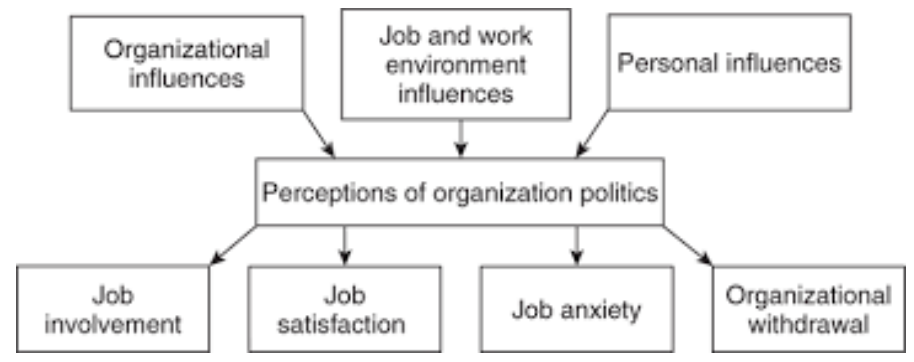

Figure 2. Perceptions of Organization Politics (Buchanan \& Badham, 2008) 
It is noteworthy that one of the striking points here is job satisfaction's being located in the figure and its being banded together with organizational politics perceptions. The conceivable outcomes of job satisfaction and organizational politics concepts can influence all the stakeholders at least in the long run. Even so "the mainstream model of organizational politics needs a more critical theory of power and the hidden dimensions of organizational politics that it elucidates." (Fischer, 2004, p.1). It would then be reasonable to speak of job satisfaction as one of the hidden components of workplace dynamics on this spot.

A handful of studies attempted to shed more light to the terms above with a specified group of employees (e.g. Ojiabo \& Aalagah, 2017) are witnessed in the literature amongst the vast number of others. Such studies outlined a negative relationship between job satisfaction and organizational politics (Drory, 1993), put forward that workers with lower levels of perceived organizational politics reached higher degrees of job satisfaction (Kodisinghe, 2010) and vice versa (Luqman, Javaid, \& Umar, 2015). It is paramount to state here that reduce in job satisfaction levels across workers is on account of organizational politics (Schneider, 2016) in many reports. For sure research to be conducted in different socio-cultural contexts-various workplaces like educational institutions in countries other than the North American is required to gain thorough understanding of job satisfaction and organizational politics.

The study aims to investigate:

a) faculty members' views on job satisfaction and their perceptions of organizational politics,

b) the relationship between job satisfaction and the perceptions of organizational politics,

c) how well faculty members' job satisfaction can predict the perceptions of organizational politics.

\section{Method}

\section{Research Model}

It was a descriptive study, which examined the research phenomenon as it was (Erkuş, 2005), designed in relational survey model (Mertens, 2010). The hypothetical research model, depicted in Figure 3 was tested with the data collected. Figure 3 indicates dependent and independent variables as well.

\begin{tabular}{|c|c|}
\hline Job Satisfaction for Faculty \\
Members \\
b) Extrinsic job satisfaction
\end{tabular}$\leftrightarrow \begin{gathered}\text { Perceptions of Organizational } \\
\text { Politics }\end{gathered}$

Figure 3. Research model showing the relationship between faculty members' job satisfaction and their perceptions of organizational politics

Dependent variables were "Go along to get ahead", "General political behavior", "Honesty / Work ethics" subscales of the Perceptions of Organizational Politics Scale (POPS) 
Questionnaire. Independent variables were the "Intrinsic job satisfaction" and "Extrinsic job satisfaction" dimensions of the Job Satisfaction Scale for Academicians (JSSA) and the JSSA total.

\section{The Study Group}

The study group consisted of 240 faculty members who work for 7 state and 7 private universities located in Ankara city. 111 of the participants were women and 129 were men. Of the participants, 31 work as research assistants, 12 as lecturers, 37 as assistant professors, 41 as associate professors, and 119 as professor doctors. 176 of them were over 40 years old.

\section{Data Collection Tools}

Data were collected using the Job Satisfaction Scale for Academicians (JSSA) developed by Kelecioğlu, Bilge and Akman (2006) alongside Perceptions of Organizational Politics Scale (POPS) Questionnaire developed by Kacmar and Ferris (1991), which was adapted to Turkish by Erol (2015) and lastly a demographic information form developed by the researchers was referred to.

\section{Job Satisfaction Scale for Academicians (JSSA)}

The JSSA consists of 2 dimensions; intrinsic job satisfaction dimension (IJSD) in which the items are related to the nature of the job and extrinsic job satisfaction dimensions (EJSD) and where the items are related to organizational policy. For the reliability of JSSA, Cronbach's Alpha coefficient were .94 for IJSD and .91 for EJSD (Kelecioğlu et al., 2006). On the other hand, no information was detected regarding Cronbach's Alpha coefficient for JSSA in any of the relevant studies like Kelecioğlu, Bilge and Akman's (2016). Yet Cronbach's Alpha coefficient were calculated as .94 for JSSA overall, .93 for IJSD and .89 for EJSD in this study. Confirmatory Factor Analysis (CFA) indicated that the goodness of fit indices, which are $\chi 2 / s d=2.679 ; R M S E A=.088 ; G F I=.083 ; C F I=.903 ; N F I=.856 ; R M R=.056$ and $S R M R=.053$, indicate good fit. The Table 1 illustrates one of the 25 items within a 5-point Likert Scale ("1" being least and " 5 " the most) presenting two-fold nature of the very concept. The first dimension is related to the existing situation which measures the extent to which the statement is valid for the participants bearing in mind their current workplaces and the second measures participant perceptions of the same conception i.e. the extent to which it (the relevant statement) needs to be the case in the workplace.

Table 1. JSSA

\begin{tabular}{|c|c|c|}
\hline Sample Item & $\begin{array}{l}\text { 1. Dimension } \\
\text { (The extent to which } \\
\text { the statement is valid } \\
\text { for the existing } \\
\text { situation) }\end{array}$ & $\begin{array}{l}\text { 2. Dimension } \\
\text { (The extent to which } \\
\text { it (the relevant } \\
\text { statement) needs to } \\
\text { be the case in the } \\
\text { workplace) }\end{array}$ \\
\hline & 4 & $\begin{array}{lllll}1 & 2 & 3 & 4 & 5\end{array}$ \\
\hline 1. My job gives me the opportunity to use my skills & $\begin{array}{llll}\mathrm{O} & \mathrm{O} & \mathrm{O} & \mathrm{O} \\
\end{array}$ & $\mathrm{O} \quad \mathrm{O} \quad \mathrm{O}$ \\
\hline
\end{tabular}

Job satisfaction - the measurement is carried out in the following way: The first dimension is subtracted from the second one. The minimum measurable score for any item is " -4 " and the maximum is " +4 ". The less the difference score is, the more job satisfaction gets. 


\section{Perceptions of Organizational Politics Scale (POPS) Questionnaire}

The POPS consist of 3 subscales: Go along to get ahead subscale (GAGAS), General political behavior subscale (GPBS), Honesty / Work ethics subscale (H/WES). The total score for the POPS cannot be calculated because each dimension of the POPS itself constitutes a subscale. It is a 5-point Likert Scale including 21 items and the minimum score that can be obtained from one item is 1 and the maximum score is 5. Cronbach's Alpha coefficient were 0.94 for POPS overall (Erol, 2015). On the other hand, Cronbach's Alpha coefficient were calculated as .88 for POPS overall, 0.86 for GAGAS, .65 for GPBS and .76 for H/WES in this study. CFA indicated that the goodness of fit indices, which are $\chi 2 / s d=2.88 ; R M S E A=.089$; $G F I=.895 ; A G F I=.872 ; C F I=.908 ; N F I=.868 ; R M R=.081$ and $S R M R=.070$, indicate good fit.

\section{Data Collection and Analysis}

Google Forms for survey were used to collect the data in September and October in 2019. The participants' email addresses were obtained through the YÖK AKADEMIKK system (https://akademik.yok.gov.tr/AkademikArama/) and emails containing the form link were sent to those addresses. Moreover, WhatsApp groups and other online platforms were made use of to be able to reach participants. It takes around 9 minutes to complete the form. The ultimate dataset included 240 data once evaluating the outliers. The relevant emails were sent to around 9000 faculty members in Ankara. 260 of them completed the form sent and 20 of these responses were excluded in the study as these were of outlier nature. This constitutes a $2.89 \%$ response rate.

The skewness and kurtosis values of the JSSA overall were .46 and -.60 respectively. And they were .96 and .28 for IJSD dimension and .26 and -.70 for EJSD dimension. They were -.17 and -.23 for Go along to get ahead subscale; .25 and -.19 for General political behavior subscale; .24 and -.55 for Honesty / Work ethics subscale. The skewness and kurtosis values were between +1.96 and -1.96 (Field, 2009). The skewness and kurtosis values point out that the normality assumption was met for the dataset. 0.05 was considered as the level of significance. Descriptive statistic (mean, standard deviation), reliability (Cronbach's Alpha coefficient), correlation (Pearson coefficient) and Multiple Linear Regression were used to analyze the data. SPSS v. 23 was resorted to. According to Russo (2004), the correlation coefficients between 0.10 - 0.29 show a weak correlation; 0.30 - 0.49 a moderate correlation and above 0.50 a strong correlation.

\section{Findings}

\section{The Perceptions of the Participants of Job Satisfaction and Organizational Politics}

Table 2 indicates the perception levels of participants on job satisfaction.

Table 2. Descriptive statistics of JSSA

\begin{tabular}{llllll}
\hline The scale total and dimensions & $\bar{X}$ & Ss & Min. & Max. & Level \\
\hline Intrinsic job satisfaction dimension & 0.71 & 0.70 & -.21 & 3.00 & Very High \\
Extrinsic job satisfaction dimension & 1.20 & 0.88 & -.45 & 3.09 & High \\
Job Satisfaction Scale & 0.93 & 0.69 & -.12 & 2.56 & Very High \\
\hline
\end{tabular}

Participants' scores on job satisfaction scale total and intrinsic job satisfaction dimension were ( $\bar{X}=.93)$ and $(\bar{X}=.71)$ respectively. It was observed that the less the scores got, the more the 
job satisfaction became (Kelecioğlu et al., 2006). Their scores on extrinsic job satisfaction dimension were $\bar{X}=1.20$. These scores exhibit that faculty members' job satisfaction regarding the nature of the job were at a very high level while regarding organizational policy were at a high level. And the total job satisfaction scores were at a very high level. Table 3 displays the perception levels of participants of "Go along to get ahead", "General political behavior" and "Honesty / Work ethics" subscales.

Table 3. Descriptive statistics of POPS Subscales

\begin{tabular}{llllll}
\hline Subscales & $\bar{X}$ & Ss & Min. & Max. & Level \\
\hline Go along to get ahead & 3.46 & 0.71 & 1.45 & 5.00 & Agree \\
General political behavior & 2.97 & 0.57 & 1.67 & 4.50 & Undecided \\
Honesty/work ethics & 3.00 & 0.83 & 1.00 & 5.00 & Undecided \\
\hline
\end{tabular}

Participants' scores on Go along to get ahead were the highest $(\bar{X}=3.46)$ and General political behavior being the lowest ( $\bar{X}=2.97$ ). These scores propose that faculty members' "go along to get ahead". However, they somehow exhibited general political behavior and they were uncertain about honesty / work ethics.

\section{The relationship between the perceptions of the participants of job satisfaction and organizational politics}

Table 4 indicates the correlation coefficients between job satisfaction and organizational politics.

Table 4. The correlations coefficients between job satisfaction and organizational politics

\begin{tabular}{lllllll}
\hline Variables & 1 & 2 & 3 & 4 & 5 & 6 \\
\hline 1. Intrinsic job satisfaction (IJS) & - & & & & & \\
2. Extrinsic job satisfaction (EJS) & $.59^{* *}$ & - & & & & \\
3. Job Satisfaction Total (JST) & $.89^{* *}$ & $.89^{* *}$ & - & & & \\
4. Go along to get ahead (GAGAS) & $.37^{* *}$ & $.38^{* *}$ & $.42^{* *}$ & - & & \\
5. General political behavior (GPBS) & $.40^{* *}$ & $.40^{* *}$ & $.45^{* *}$ & $.59^{* *}$ & - & \\
6. Honesty / work ethics (H/WES) & $.37^{* *}$ & $.47^{* *}$ & $.48^{* *}$ & $.37^{* *}$ & $.42^{* *}$ & - \\
$\mathrm{n}=240 ; * * \mathrm{p}<.01$ & & & & & &
\end{tabular}

There was a positive and "moderate" correlation between IJS and GAGAS $(r=.37 ; p<.01)$; between IJS and GPBS $(r=.40 ; p<.01)$ and between IJS and H/WES $(r=.37 ; p<.01)$. There was a positive and "moderate" correlation between EJS and GAGAS $(r=.38 ; p<.01)$; between EJS and GPBS $(r=.40 ; p<.01)$ and between EJS and H/WES $(r=.47 ; p<.01)$. There was a positive and "moderate" correlation between JST and GAGAS $(r=.42 ; p<.01)$; between JST and GPBS $(r=.45 ; p<.01)$ and between JST and H/WES $(r=.48 ; p<.01)$. The correlation between JST and H/WES were very close to "strong".

\section{The views of the participants of their job satisfaction and prediction of their perceptions of organizational politics}

The results of multiple regression analysis were employed to examine how well faculty members' job satisfaction predicted their perceptions of organizational politics. Table 5 shows the results of the multiple regression analysis for the JSSA's dimensions as a predictor of the POPS's "Go along to get ahead" subscale. 
Table 5. The scores of the multiple regression analysis for the JSSA's dimensions as a predictor of the POPS's "Go along to get ahead" subscale.

\begin{tabular}{lllllll}
\hline Dependent variables & Independent variables & $B$ & $S E$ & $\beta$ & $t$ & $p$ \\
\hline \multirow{3}{*}{ Go along to get ahead } & Constant & 3.06 & .07 & - & 42.73 & $.000^{* *}$ \\
& Intrinsic job satisfaction & .22 & .07 & .22 & 2.96 & $.003^{* *}$ \\
& Extrinsic job satisfaction & .20 & .06 & .25 & 3.46 & $.001^{* *}$ \\
\hline
\end{tabular}

$\mathrm{F}=25.23 ; \mathrm{R}=.42 ; \mathrm{R}^{2}=.18 ; * * \mathrm{p}<.01$

The JSSA's intrinsic job satisfaction and extrinsic job satisfaction dimensions significantly predicted the POPS's "Go along to get ahead" subscale $(\mathrm{F}=25.23, \mathrm{p}<.01)$. Those independent (predictive) variables together accounted for $18 \%$ of the total variance in the POPS's "Go along to get ahead" subscale score $\left(\mathrm{R}=.42, \mathrm{R}^{2}=.18\right)$. The standardized regression coefficients $(\beta)$ indicate that the predictive power of the extrinsic job satisfaction dimension is more than the intrinsic job satisfaction dimension. The mathematical model for the JSSA's dimensions as a predictor of the POPS's "Go along to get ahead" subscale is:

The score of "Go along to get ahead" subscale (Model 1) $=3.06+0.22$ (Intrinsic job satisfaction score) +0.20 (Extrinsic job satisfaction score)

Table 6 shows the results of the multiple regression analysis for the JSSA's dimensions as a predictor of the POPS's "General political behavior" subscale.

Table 6. The scores of the multiple regression analysis for the JSSA's dimensions as a predictor of the POPS's "General political behavior" subscale.

\begin{tabular}{lllllll}
\hline Dependent variables & Independent variables & $B$ & $S E$ & $\beta$ & $t$ & $p$ \\
\hline \multirow{3}{*}{ General political behavior } & Constant & 2.62 & .06 & - & 46.24 & $.000^{* *}$ \\
& Intrinsic job satisfaction & .20 & .06 & .25 & 3.46 & $.001^{* *}$ \\
& Extrinsic job satisfaction & .17 & .05 & .26 & 3.57 & $.000^{* *}$ \\
\hline
\end{tabular}

$\mathrm{F}=30.16 ; \mathrm{R}=.45 ; \mathrm{R}^{2}=.20 ; * * \mathrm{p}<.01$

The JSSA's intrinsic job satisfaction and extrinsic job satisfaction dimensions significantly predicted the POPS's "General political behavior" subscale $(\mathrm{F}=30.16, \mathrm{p}<.01)$. Those independent (predictive) variables together accounted for $20 \%$ of the total variance in the POPS's "General political behavior" subscale score $\left(\mathrm{R}=.45, \mathrm{R}^{2}=.20\right)$. The standardized regression coefficients $(\beta)$ indicate that the predictive power of the extrinsic job satisfaction dimension is more than the intrinsic job satisfaction dimension. The mathematical model for the JSSA's dimensions as a predictor of the POPS's "General political behavior" subscale is:

The score of "General political behavior" subscale $($ Model 2) $=2.62+0.20$ (Intrinsic job satisfaction score) +0.17 (Extrinsic job satisfaction score)

Table 7 shows the results of the multiple regression analysis for the JSSA's dimensions as a predictor of the POPS's "Honesty/work ethics" subscale.

Table 7. The scores of the multiple regression analysis for the JSSA's dimensions as a predictor of the POPS's "Honesty/work ethics" subscale.

\begin{tabular}{lllllll}
\hline Dependent variables & Independent variables & $B$ & $S E$ & $\beta$ & $t$ & $p$ \\
\hline \multirow{3}{*}{ Honesty/work ethics } & Constant & 2.44 & .08 & - & 30.32 & $.000^{* *}$ \\
& Intrinsic job satisfaction & .17 & .08 & .14 & 2.03 & $.044^{*}$ \\
& Extrinsic job satisfaction & .37 & .07 & .39 & 5.58 & $.000^{* *}$ \\
\hline $\mathrm{F}=37.25 ; \mathrm{R}=.49 ; \mathrm{R}^{2}=.24 * * 05 ; * * \mathrm{p}<.01$ & & & & &
\end{tabular}

$\mathrm{F}=37.25 ; \mathrm{R}=.49 ; \mathrm{R}^{2}=.24 ;{ }^{*} \mathrm{p}<.05 ; * * \mathrm{p}<.01$

The JSSA's intrinsic job satisfaction and extrinsic job satisfaction dimensions significantly 
predicted the POPS's "Honesty/work ethics" subscale $(\mathrm{F}=25.23, \mathrm{p}<.05)$. Those independent (predictive) variables together accounted for $24 \%$ of the total variance in the POPS's "Honesty/work ethics" subscale score $\left(\mathrm{R}=.49, \mathrm{R}^{2}=.24\right)$. The standardized regression coefficients $(\beta)$ indicate that the predictive power of the extrinsic job satisfaction dimension is more than the intrinsic job satisfaction dimension. The mathematical model for the JSSA's dimensions as a predictor of the POPS's "Honesty/work ethics" subscale is:

The score of "Honesty/work ethics" subscale (Model 3) $=2.44+0.17$ (Intrinsic job satisfaction score) +0.37 (Extrinsic job satisfaction score)

\section{Discussion and Conclusion}

The current research studied both the level of faculty members' views on their job satisfaction and their perceptions of organizational politics and the relationship between faculty members' job satisfaction and also the perceptions of organizational politics. And this research examined how well faculty members' job satisfaction predicted their perceptions of organizational politics.

The faculty members' job satisfaction total scores were at a very high level. This result was similar to other research results (Çelikkalp, Temel, \& Bilgiç, 2019; Karadağ, Karataş, \& Yücel, 2018; Masum, Azad, \& Beh, 2015; Öztürk, \& Şahbudak, 2015; Bilge, Akman, \& Kelecioğlu, 2007). For example, Çelikkalp, Temel, and Bilgiç (2019) reported that the total job satisfaction of academicians is good. However, this result was not consistent with the result gathered by Öztürk and Şahbudak (2017) and Bayar and Öztürk (2017). Öztürk and Şahbudak shared that the job satisfaction of the research assistants was below moderate level while Bayar and Öztürk reported a moderate level. The nature of the job scores as one of the sub-dimensions was at a very high level as well. However, organizational policy ones were at a high level. It can be inferred from the JSS items that the work carried out by faculty members in relation to their intrinsic job satisfaction allows for using their skills, gaining novel experiences and taking over responsibilities in the workplace. Also, it can be stated that the levels are high with respect to such work's being consistent with their capacities and capabilities; their resorting to unique methods of their own and to creativity; their learning new things continuously and taking their own decisions. Additionally, as regards their extrinsic job satisfaction the levels are high for the following issues: colleagues' being supportive of working hard, equal distribution of workload, recognition of experience, establishing a good rapport with managers, employees' doing what they are supposed to be doing, clearly defined expectations.

On the other hand, faculty members' scores of "Go along to get ahead" were highest and it means that they are inclined to Go along to get ahead. Faculty members seem to believe that irrespective of the quality of the work carried out, one can achieve whatever is wanted to be achieved through 'being everyone's friend'; getting on well with everyone, knowing the 'right' people with critical positions. In cases where rules are not explicitly set, it is thought that employees set rules for themselves and that during times of crisis and uncertainty the ones who can get out from under through surreptitious means make progress. Nevertheless, they somehow exhibit general political behavior and are uncertain about Honesty / Work ethics. The former result is not consistent with the result underlining that political behavior is frequently perceived in faculties of Education (Erol \& Kunt, 2018). The participants neither agree nor disagree with the issues that could be listed as: not providing/partial providing of any information requested from them, others' manipulating such information for the sake of their self-interest, informing employees about the policies of salary and promotion, colleagues' being helpful to others. In addition to these, they neither agree nor disagree with these: disregarding 
workers who are 'yea-sayers', workers' wishing to come up with good ideas though it may cause conflict with superiors, employees' being encouraged to tell what they believe although this would mean criticism over the views 'according to the book', outperformers' getting promotion and rewards.

Aybar and Marşap (2018) used the perception of organizational politics scale developed by Ferris and Kacmar (1992). They found that the perception of the faculty members working in the Faculties of Economics and Administrative Sciences was "weak". However, in a similar study, Salam (2016) used the perception of organizational politics scale developed by Kacmar and Carlson (1997). He found that perception of faculty members in Thailand were at the level of very high.

The JSSA subscales were moderately and positively correlated with the POPS subscales. That is, the JSSA's both IJS and EJS subscales and JST were moderately and positively correlated with the POPS's subscales GAGAS, GPBS and H/WES. These correlations coefficients suggest that the higher the level of the faculty members' view of job satisfaction in total (JST), intrinsic job satisfaction (IJS) and extrinsic job satisfaction (EJS); the higher the level of their perceptions of going along to get ahead (GAGAS), General political behavior (GPBS) and Honesty / Work ethics (H/WES) become. It can be disclosed that these results are not consistent with those reported by Salam (2016). He found out that there was a significant negative relationship between job satisfaction and perceived organizational politics of faculty members in Thailand. Nonetheless, the "General political behavior" and "Pay and promotion policy" subscales of organizational politics have a significant negative relationship with job satisfaction while "Go along to get ahead" dimension does not (Salam, 2016).

In a similar study, Khali and Ahmed (2016) found a positive relationship between organizational politics and employee silence motives. Aybar and Marşap (2018) revealed that the perceptions of organizational policy were positively related to both organizational trust levels of the academicians and organizational commitment levels. Erol and Kunt (2018) found a positive relationship between the perception of organizational policy and bureaucratic climate. In another study, Öztürk and Şahbudak (2017) declared that there was a negatively and moderately significant relationship between psychological harassment and job satisfaction in the workplace. Through their research, Inandi, Tunç and Uslu (2013) informed the literature that there was a meaningful relationship between career barriers and job satisfaction of faculty members.

The regression results indicated that the JSSA's intrinsic job satisfaction and extrinsic job satisfaction dimensions significantly and positively predicted the POPS's "Go along to get ahead", "General political behavior" and "Honesty/work ethics" subscales. Mathematical formulas to calculate the effect of the increase in the level of the job satisfaction on the increase in the perception of organizational policy are presented in Model 1, Model 2 and Model 3. In a similar study, organizational trust predicted the perceptions of organizational policy (Aybar \& Marşap, 2018). Erol and Kunt (2018) notified that bureaucratic climate and supportive climate dimensions were found to be an important (significant) predictor of "Go along to get ahead", "General political behavior" and "Honesty/work ethics" subscales, while the innovative climate dimension was not.

Two indispensable concepts of organizational dynamics: job satisfaction and organizational politics may interplay due to the fact that both include elements which chiefly impact attitude, behaviors, choices, and social networking of employees along with affecting managers and the 
global characteristics of any institution/workplace. For this reason, managers of any organization/institution are expected to make sure that they gain more insights into the terms; job satisfaction and organizational politics so that they could stop their interfering with each other (Breaux et.al, 2009).

In this respect, policies can be developed in the context of motivation resources and management of the members of the organization to increase the job satisfaction of academicians. Lecturing workload, research workload, working hours planning can carefully be done on the basis of the needs of the members of the organization. These political arrangements can also be seen in the findings of this study in which the members of the organization will have increased perceptions of organizational policy.

Last but not the least, the quantitative measurement tools and a descriptive relational survey model used to solve the problems, the date of the data collection, the universities in Ankara and the numbers of the participants all form the limitations of this research. To this end, future research can be carried out on faculty members of other universities in Turkey using different measurement tools and with a possibility of referring to qualitative mixed methods that investigate the job satisfaction and the perceptions of organizational politics.

\section{References}

Ahsan, N., Abdullah, Z., Fie, D. Y. G., \& Syed Shah Alam, S. S. A. (2009). A study of job stress on job satisfaction among university staff in Malaysia: Empirical study. European Journal of Social Sciences, 8(1), 121-131.

Ali, T., \& Akhter, I. (2009). Job satisfaction of faculty members in private universities-in context of Bangladesh. International Business Research, 2(4), 167-175. DOI: 10.5539/ibr.v2n4p167

Alqashan, H. F. (2013). Job satisfaction among counselors working at stress center social development office- in Kuwait. Traumatology, 15(1), 29-39.

Al-Rubaish, A. M., Rahim, S. I., Abumadini, M. S., \& Wosornu, L. (2011). Academic job satisfaction questionnaire: Construction and validation in Saudi Arabia. J Family Community Med, 18, 1-7. DOI: 10.4103/1319-1683.78630

Altuntaş, S. (2014). Örgütsel güven ölçeğinin hemşirelikte geçerlik-güvenirliği [Validity and Reliability of Organizational Trust Scale in Nursing]. Florence Nightingale Journal of Nursing, 18 (1), 10-18.

Aryee, S., Chen, Z. X., \& Budhwar, P. S. (2004). Exchange fairness and employee performance: An examination of the relationship between organizational politics and procedural justice. Organizational Behavior and Human Decision Processes, 94, 1-14.

Aslan, A. S., Shaukat, M. Z., Ahmed, I., Shah, I. M., \& Mahfar, M. (2014). Job satisfactions of academics in Malaysian public universities. Procedia-Social and Behavioral Sciences, 114, 154-158. DOI:10.1016/j.sbspro.2013.12.676

Aybar, S., \& Marşap, A. (2018). The moderating role of organizational trust on the relationship between perception of organizational politics and organizational commitment: research in Istanbul University. Journal of Business Research Turk, 10(2), 758-782.

Banerjee, P. A. (2016). A systematic review of factors linked to poor academic performance of disadvantaged students in science and maths in schools. Cogent Education, 3(1), 1178441. DOI: 10.1080/2331186X.2016.1178441

Başar, U. \& Basım, N. (2015). Effects of organizational identification on job satisfaction: Moderating role of organizational politics. Journal of Management and Economics, 22(2), 663-683. 
Başar, U., \& Varoğlu, K. (2016). Intention to quit as a mediator of the relationship between perceptions of organizational politics and neglect of work. Journal of Management and Economics, 23(3), 751-765. DOI: 10.18657

Bayar, H. T., \& Öztürk, M. (2017). Examination of job satisfaction and job stress on the research assistant: example of Süleyman Demirel University. Suleyman Demirel University Journal of Faculty of Economics \& Administrative Sciences, 22(2), 525-546.

Bell, R. C., \& Weaver, J. R. (1987). The dimensionality and scaling of job satisfaction: An internal validation of the worker opinion survey. Journal of Occupational Psychology, 60(2), 147-155.

Bernard, B. (2012). Factors that determine academic staff retention and commitment in private tertiary institutions in Botswana: Empirical review. Global Advanced Research Journal of Management and Business Studies, 1(9), 278-299.

Bilge, F., Akman, Y., \& Kelecioğlu, H. (2007). Öğretim elemanlarının iş doyumlarının incelenmesi [Examining the job satisfaction of academics]. Hacettepe Üniversitesi Eğitim Fakültesi Dergisi/Hacettepe University Journal of Education, 32(32), 32-41.

Bodla, M. A., \& Danish, R. Q. (2009). Politics and workplace: an empirical examination of the relationship between perceived organizational politics and work performance. South Asian Journal of Management, 16(1), 44-62.

Bogler, R. \& Nir, A. (2012). The importance of teachers' perceived organizational support to job satisfaction, Journal of Educational Administration, 50(3), 287-306. DOI: 10.1108/ 09578231211223310

Breaux, D. M., Munyon, T. P., Hochwarter, W. A., \& Ferris, G. R. (2009). Politics as a Moderator of the Accountability-Job Satisfaction Relationship: Evidence Across Three Studies. Journal of Management, 35(2), 307326. DOI:10.1177/01492063083186 21

Buchanan, D. A. \& Badham, R. J. (2008). The terminology game: defining power and politics. In Power, politics, and organizational change: Winning the turf game (pp. 40-82). London: SAGE Publications Ltd DOI: 10.4135/9781446280300.n2

Buchanan, D. A. (2008). You stab my back, I'll stab yours: management experience and perceptions of organization political behaviour. British Journal of Management, 19(1), 49-64.

Byrne, Z. S., Manning, S. G., Weston, J. W., \& Hochwarter, W. A. (2017). All roads lead to well-being: Unexpected relationships between organizational politics perceptions, employee engagement, and worker well-being. In, C. Rosen and P. Perrewé (Eds.), Power, Politics, and Political Skill in Job Stress: Research in Occupational Stress and Wellbeing. Bingle: Emerald Publishing.

Cacciattolo, K. (2015). Organisational politics: the positive and negative sides. European Scientific Journal, 11(1), 121-129.

Caulton, J. R. (2012) The development and use of the theory of ERG: a literature review, Emerging Leadership Journeys, 5(1), 2-8.

Çekmecelioğlu, H. (2006). İş tatmini ve örgütsel bağlılık tutumlarının işten ayrılma niyeti ve verimlilik üzerindeki etkilerinin değerlendirilmesi: bir araştırma [Evaluation of effect of work satisfaction and organizational commitment on intention to leave and productivity: A research]. "İş, Güç” Endüstri Illişkileri ve Insan Kaynakları Dergisi/ "Is, Guc" The Journal of Industrial Relations and Human Resources, 8(2), 153-168.

Çelikkalp, Ü., Temel, M., \& Bilgiç, Ş. (2019). Akademisyenlerin İş Doyumu ve Etkileyen Faktörler. [Academicians' job satisfaction and effective factors] Yüksekögretim Dergisi/Journal of Higher Education, 9(1), 59-66. DOI: 10.2399/yod.18.031 
Dave, N., \& Raval, D. (2014). A research on the factors influencing job satisfaction of MBA faculty in Gujarat state. International Journal of Advance Research in Computer Science and Management Studies, 2(2), 218-223.

Doldor, E. (2007). Conceptualizing and investigating organizational politics: A systematic review of the literature. M.S. thesis; Cranfield: Cranfield University.

Drory, A. (1993). Perceived political climate and job attitudes. Organization Studies, 14(1), 5971. DOI:10.1177/017084069301400105

Drory, A., \& Vigoda-Gadot, E. (2010). Organizational politics and human resource management: A typology and the Israeli experience. Human Resource Management Review, 20(3), 194-202.

Eldor, L. (2017). Looking on the bright side: the positive role of organisational politics in the relationship between employee engagement and performance at work. Applied Psychology, 66(2), 233-259. DOI:10.1111/apps.12090

Erkuş, A. (2005). Bilimsel araştırma sarmalı. Ankara: Seçkin Yayıncılık.

Erol, E. \& Kunt, M. (2018). Eğitim Fakültelerinde Örgütsel İklim ile Örgütsel Politika Algısı Arasındaki İlişkiler [The relationship between organizational climate and perceptions of organizational politics in educational faculties]. Pamukkale Üniversitesi Eğitim Fakültesi Dergisi/ Pamukkale University Journal of Education, 43 (43), 15-29.

Erol, E. (2015). Perceptions of Organizational Politics Scale (POPS) Questionnaire into Turkish: A Validity and Reliability Study. International Journal of Assessment Tools in Education, 2(1), $58-78$.

Erol, E. (2016). Perceptions of organizational politics scale (POPS) questionnaire into Turkish: A validity and reliability study. International Journal of Assessment Tools in Education, 2(1), 58-78. DOI: $10.21449 /$ ijate.239566

Farrell, D.J. (1978). A causal model of job satisfaction. Dissertation Abstracts International, 38(7), 4399-4400.

Ferris, G.R. \& Kacmar, M.K. (1992). Perceptions of organizational politics. Journal of Management, 18(1), 93-116.

Field, A. (2009). Discovering statistics using SPSS (3. Ed.). London: SAGE Press.

Fisher, D.M. (2004). The business process maturity model. A practical approach for identifying opportunities for optimization. Retrieved from http://www.bptrends.com/bpt/wpcontent/publicationfiles/10-04\%20ART\%20BP\%20Maturity\%20Model\%20\%20Fisher.pdf

Gautam, M., Mandal, K., \& Dalal, R. S. (2006). Job satisfaction of faculty members of veterinary sciences: an analysis. Livestock Research for Rural Development, 18(6), 089.

Ghaffar, A., Ameer, B. Arshad, N., \& Urooj, F. (2013). Factors affecting job satisfaction level of academic staff in Pakistan. Journal of Education and Practice, 4(6), 181-203.

Gotsis, G. N., \& Kortezi, Z. (2010). Ethical considerations in organizational politics: Expanding the perspective. Journal of Business Ethics, 93(4), 497-517.

Gül, H., Oktay, E., \& Gökçe, H. (2008). İş tatmini, stres, örgütsel bağl1lık, işten ayrılma niyeti ve performans arasındaki ilişkiler: sağlık sektöründe bir uygulama [The relationships among job satisfaction, stress, organizational commitment, intention to leave and performance] Akademik Bakış, 15, 1-15.

Hackman, J.R. \& Oldham, G.R. (1975). Development of the job diagnostic survey. Journal of Applied Psychology, 60(2), 159-170. DOI: 10.1037/h0076546

Hackman, J.R., \& Oldham, G.R. (1976). Motivation through the design of work: Test of a theory. Organizational Behavior and Human Performance, 16(2), 250-279.

Haque, M.F., Haque, M.A., \& Islam, M.S. (2014). Motivational theories - a critical analysis. ASA University Review, 8(1), 61-68. 
Harris, K. \& Kacmar, K. (2005). Organizational politics. In J. Barling, E. K. Kelloway \& M. R. Frone (eds.), Handbook of work stress (pp. 353-374). Thousand Oaks, CA: SAGE Publications, Inc. DOI: 10.4135/9781412975995.n14

Heath, C., \& Sitkin, S.B. (2001). Big-B versus Big-O: What is organizational about organizational behavior? Journal of Organizational Behavior 22(1), 43-58. DOI:10.1002/job.77

Heathfield, S. M. (2016). Simple ideas for improving employee morale in your workplace. Retrieved from https://www.thebalance.com/you-can-boost-employee-morale1918107.

Hellriegel, D., Slocum, Jr.W.J., \& Woodman, W.R. (1995). Organizational behavior. St. Paul: West Publishing Company.

Herzberg, F. (1966). Work and the nature of man. New York: The World Publishing Company. Herzberg, F., Mausner, B., \& Snyderman, B.B. (1959). The motivation to work (2nd ed.). NewYork: John Wiley \& Sons.

Hochwarter, W.A., Ferris, G.R., Laird, M.D., Treadway, D.C., \& Coleman Gallagher, V. (2010). Nonlinear Politics Perceptions-Work Outcomes Relationships: A Three-Study, Five-Sample Investigation. Journal of Management, 36(3), 740-763. DOI: 10.1177/ $\underline{0149206308324065}$

Hoppock, R. (1935). Job satisfaction. New York: Harper and Brothers.

Hoy, W.K., \& Miskel, C.G. (2008). The school as a social system. In educational administration. Theory, research, and practice. (8th ed.). Boston, MA: McGraw Hill.

Huseman, R.C., Hatfield, J.D. \& Miles, E.W. (1987). A new perspective on Equity Theory: the equity sensitivity construct, The Academy of Management Review, 12(2), 222-234.

İnan, E.İ., \& Çelik, E. (2018). Perceived organizational trust and business satisfaction: an application in the private and public banks in Kastamonu. Injosos Al-Farabi International Journal on Social Sciences, 2(3), 23-52.

İnandi, Y, Tunç, B, \& Uslu, F. (2013). Eğitim fakültesi öğretim elemanlarının kariyer engelleri ile iş doyumları arasındaki ilişki [Relationship between job satisfaction and career barriers for the academic staff of the education faculties]. Eğitim Bilimleri Araştırmaları Dergisi/ Journal of Educational Sciences Research, 3(1), 219-238.

Jiménez, P. (2008). PAZ Profilanalyse der arbeitszufriedenheit. Manual Wiener testsystem (profile analysis of job jatisfaction. Test manual in Vienna test system). Mödling: Schuhfried GmbH.

Julius, N.T., Ojiabo, U., \& Alagah, A.D. (2017). Organizational politics and employee's job satisfaction in the health sector of rivers state. IJARR International Journal of Advanced Academic Research, 3(7), 88-106.

Kacmar K. M. and Ferris G.R., (1991). Perceptions of Organizational Politics Scale (POPS): Development and construct validation. Educational and Psychological Measurement, 51(1), 193-205.

Kacmar, K. M., \& Carlson, D. S. (1997). Further validation of the perceptions of politics scale (POPS): A multiple sample investigation. Journal of Management, 3(5), 627-658.

Karadağ, T. F., Karataş, Ö., \& Yücel, A. S. (2018). Öğretim elemanlarinin demografik özelliklerinin iş doyumu düzeylerine etkisi (Ardahan Üniversitesi Örneği) [The effect of demographic characteristics of academic staff on their job satisfaction level (Ardahan University example)]. Turkish Studies Social Sciences, 13(26), 745-755.

Kelecioğlu, H., Bilge, F., \& Akman, Y. (2006). Öğretim elemanları iş doyumu ölçeğinin geliştirilmesi [Developing job satisfaction scale for Turkish academicians]. Türk Psikolojik Danışma ve Rehberlik Dergisi/Turkish Psychological Counseling and Guidance Journal, 3(26), $115-128$

Khalid, J., \& Ahmed, J. (2016). Perceived organizational politics and employee silence: supervisor trust as a moderator. Journal of the Asia Pacific Economy, 21(2), 174-195. 
Khalid, S., Irshad, M. Z., \& Mahmood, B. (2012). Job satisfaction among academic staff: A comparative analysis between public and private sector universities of Punjab, Pakistan. International Journal of Business \& Management, 7(1), 126-136.

Khan, M.A. (2012). Ethical values and work related outcomes: An empirical study of Pakistani organizations. African Journal of Business Management, 6(11), 3977-3987.

Kinicki, A. (2008). Organizational behavior core concepts. Boston, MA: McGraw-Hill.

Kodisinghe, K. (2010). Impact of perceived organizational politics on employees' job satisfaction in the commercial banking sector of Sri Lanka. $2^{\text {nd }}$ International Conference Business and Information, Kuliyapitiya,

Kurchner-Hawkins, R., \& Miller, R. (2006). Organizational politics. Building positive political strategies in turbulent times. In E. Vigoda-Gadot \& A. Drory (eds.), Handbook of organizational politics (pp. 328-351). Cheltenham, UK: Edward Elgar Publishing.Küskü, F. (2001), Dimensions of employee satisfaction: A state university example. METU Studies in Development, 28(3), 399-430.

Kylén, S. (1999). Interaktionsmönster $i$ arbetsgrupper, offensiva och defensiva handling srutiner. Psykologiska Institutionen, Göteborgs Universitet, FENIX forskningsprogram, IMIT, Göteborg.

Lepold, A., Tanzer, N., Bregenzer, A., \& Jiménez, P. (2018). The efficient measurement of job satisfaction: Facet-items versus facet scales. International Journal of Environmental Research and Public Health, 15(7), 2-19.

Lester, P.E. (1987). Development and Factor Analysis of the Teacher Job Satisfaction Questionnaire (TJSQ). Educational and Psychological Measurement, 47(1), 223233. DOI: $10.1177 / 0013164487471031$

Lin, C.C. (1992). Greater Kaohsiung Medical Center physician job satisfaction. Theses of Institute of Hospital and Health Care Administration, National Yang-Ming University, 1992, 1-53.

Locke, E.A. \& Latham, G.P. (2002). Building a practically useful theory of goal setting and task motivation A 35-Year Odyssey, American Psychologist, 57(9), 705-717. DOI: 10.1037/ 0003-066X.57.9.705

Locke, E.A. (1976). The nature and causes of job satisfaction. In M. D. Dunnette (ed.), Handbook of industrial and organizational psychology (pp. 1297-1349). Chicago: Rand McNall.

Lu, L., Lu, A., Gursoy, D. \& Neale, N. (2016), Work engagement, job satisfaction, and turnover intentions. International Journal of Contemporary Hospitality Management, 28(4), 737-761. DOI: 10.1108/IJCHM-07-2014-0360

Lundberg, C., Gudmundson, A., \& Andersson, T.D. (2009). Herzberg's two-factor theory of work motivation tested empirically on seasonal workers in hospitality and tourism. Tourism Management, 30(6), 890-899.

Luqman, M.K., Javaid, M.F. \& Umar, T. (2015). Combined effects of perceived organizational politics and emotional intelligence on job satisfaction and counterproductive work behaviours. European Online Journal of Natural and Social Sciences, 4(4), 891-911.

Machado-Taylor, M.L., Meira Soares, V., Ferreira, J.B. \& Gouveia, O.M.R. (2011). What factors of satisfaction and motivation are affecting the development of the academic career in Portuguese higher education institutions?. Revista de Administração Pública 45(1), 33-44. DOI: 10.1590/S0034-76122011000100003

Masum, A.K.M., Azad, M.A.K., \& Beh, L.S. (2015). Determinants of academics' job satisfaction: Empirical evidence from private universities in Bangladesh. PloS one, 10(2).

Mau, W-C., Ellsworth, R., \& Hawley, D. (2008). Job satisfaction and career persistence of beginning teachers. The International Journal of Educational Management, 22(1), 4861. 
McClelland, D.C. (1976). The achieving society. New York: Irvington Publishers.

Mehta, S. (2012). Job satisfaction of teachers. IUP Journal of Organizational Behavior, 11(2).

Mertens, D.M. (2014). Research and evaluation in education and psychology: Integrating diversity with quantitative, qualitative, and mixed methods. California: Sage Publications.

Miller, B.K., Rutherford, M.A., \& Kolodinsky, R.W. (2008). Perceptions of organizational politics: A meta-analysis of outcomes. Journal of Business and Psychology, 22(3), 209222. DOI:10.1007/s 10869-008-9061-5

Mintzberg, H. (1985). The organization as political arena. Journal of Management Studies, 22(2), 133-154. DOI:10.1111/j.1467-6486.1985.tb00069.x

Moen, P., Kelly, E.L., \& Lam, J. (2013). Healthy work revisited: do changes in time strain predict well-being?, Journal of Occupational Health Psychology, 18(2), 157-172. DOI: http://dx.DOI.org/10.1037/a0031804.

Othman, R. (2008). Organisational politics: The role of justice, trust and job ambiguity. Singapore Management Review, 30(1), 43-53.

Özel, N. (2014). Effect of job security, job satisfaction and organizational identification on intention to remain: a research on employees of manufacturing sector in Bolu. Yönetim ve Ekonomi Araştırmalart Dergisi/Journal of Management and Economics, 24, 262-280. DOI: 10.11611/JMER366

Öztürk, M., \& Şahbudak, E. (2015). Akademisyenlikte Iş Doyumu [Job satisfaction in academia]. Journal of International Social Research, 8(40), 494-501.

Öztürk, M., \& Şahbudak, E. (2017). İşyerinde psikolojik taciz (mobbing) ve iş doyumu: Cumhuriyet Üniversitesindeki araştirma görevlileri üzerine bir çalişma [Mobbing and job satisfaction: a study on research assistants working at Cumhuriyet university]. Sosyoloji Araştırmaları Dergisi/Journal of Sociological Research, 20(2), 200-228.

Özyer, K. (2010). Etik iklim ve işten ayrılma niyeti arasındaki ilişkide örgütsel bağlılık ve iş tatmininin düzenleyici rolü [The moderator role of organizational commitment and job satisfaction upon the relation between ethical climate and turnover intention]. Hacettepe Üniversitesi Sosyal Bilimler Enstitüsü, Yayınlanmamış Doktora Tezi/Unpublished doctoral dissertation, Ankara.

Pepe, A., Addimando, L., \& Veronese, G. (2017). Measuring teacher job satisfaction: Assessing invariance in the teacher job satisfaction scale (TJSS) across six countries. Europe's Journal of Psychology, 13(3), 396-416. DOI: 10.5964/ejop.v13i3.1389

Poon, J. (2003). Situational antecedents and outcomes of organizational politics perceptions. Journal of Managerial Psychology, 18(2), 138-155. DOI:10.1108/02683940310465036

Randall, M., Cropanzano, R., Bormann, C., \& Birjulin, A. (1999). Organizational politics and organizational support as predictors of work attitudes, job performance, and organizational citizenship behavior. Journal of Organizational Behavior. 20(2), 159174.

Randhawa G. (2007). Relationship between job satisfaction and turnover intentions: An empirical analysis. Indian Management Studies Journal, 11(2), 149-159.

Ravari, A., Bazargan-Hejazi, S., Ebadi, A., Mirzaei, T., \& Oshvandi, K. (2013). Work values and job satisfaction: A qualitative study of Iranian nurses. Nursing Ethics, 20(4), 448458.

Reddy, S.J., Reddy, B.V., \& Rao, S.D. (2016). A study on axis bank employees' job satisfaction levels in Andhra Pradesh. Innovative Journal of Business and Management, 5(5), 102110.

Rosen, C.C., \& Hochwarter, W.A. (2014). Looking back and falling further behind: The moderating role of rumination on the relationship between organizational politics and employee attitudes, well-being and performance. Organizational Behavior \& Human Decision Processes, 124(2), 177-189.

Russo, R. (2004). Statistics for the behavioral sciences: An introduction. Taylor \& Francis e-Library. 
Salam, A. (2016). Relationship between Perceived Organizational Politics, Supportive Organizational Climate and Job Satisfaction in Thai Higher Education Sector. Mediterranean Journal of Social Sciences, 7(5), 396-403.

Salancik, G.R., \& Pfeffer, J. (1978). A social information processing approach to job attitudes and task design. Administrative Science Quarterly, 23, 224 -253.

Schneider, R.C. (2016). Understanding and managing organizational politics. Kinesiology, Sport Studies and Physical Education Presentations and Papers. 14.

Searle, B.J., \& Auton, J.C. (2015). The merits of measuring challenge and hindrance appraisals. Anxiety, Stress, \& Coping, 28(2), 121-143. DOI: 10.1080/10615806.2014.931378.

Seashore, S.E., \& Taber, T.D. (1975). Job satisfaction indicators and their correlates. American Behavioral Scientist, 18(3), 333-368. DOI: 10.1177/000276427501800303

Seniwoliba, A.J. (2013). Teacher motivation and job satisfaction in senior high schools in the Tamale metropolis of Ghana. Journal of Education and Review, 1(9), 181-196.

Sıdık, M.H.M., Ab Hamid, M.R., Ibrahim, A., \& Ali, Z.M. (2017). Theoretical support for staff satisfaction in higher education institutions: A conceptual framework. Journal of Quality Measurement and Analysis, 13(2), 1-6.

Stacey, R.D. (1996). Complexity and creativity in organizations. San Francisco: Berret-Koehler Publishers.

Strydom, A. (2011). The job satisfaction of academic staff members on fixed-term employment contracts at South African higher education institutions. Ph.D. Thesis, University of Free State, Bloemfontein.

Sussman, E., Winkler, I., Huotilainen, M., Ritter, W., \& Näätänen, R. (2002). Top-down effects on stimulus-driven auditory organization. Cognitive Brain Research, 13(3), 393-405.

Swaminathan, S., \& Jawahar, P.D. (2013). Job satisfaction as a predictor of organizational citizenship behaviour: An empirical study. Global Journal of Business Research, 7(1), 71-80.

Swamy, D.R., Nanjundeswaraswamy, T.S., \& Rashmi, S. (2015). Quality of work life: Scale development and validation. International Journal of Caring Sciences, 8(2), 281-300.

Talaue, M.G. (2016). Motivational needs among college students: an assessment using Thematic Apperception Test (TAT), International Journal of Scientific Research and Innovative Technology, 3(9), 48-65.

Thompson, E.R., \& Phua, F.T.T. (2012). A brief index of affective job satisfaction. Group \& Organization Management, 37(3), 275-307. DOI:10.1177/1059601111434201

Toker, B. (2011). Job satisfaction of academic staff: An empirical study on Turkey. Quality Assurance in Education, 19 (2), 156-169.

Tschopp, C., Grote, G., \& Gerber, M. (2014). How career orientation shapes the job satisfaction-turnover intention link. Journal of Organizational Behavior, 35(2), 151171. DOI:10.1002/job.1857.

Ulkeryildiz, R.E. (2009). Political tactics in building construction industry from the architects' perspective. Izmir Institute of Technology: A thesis submitted to the Graduate School of Engineering and Science.

Usop, A.M., Kadtong, M.L., \& Usop, D.A.S.O. (2013). The significant relationship between work performance and job satisfaction in Philippines. International Journal of Human Resource, 3(2), 9-16.

Valle, M., \& Perrewe, P.L. (2000). Do politics perceptions relate to political behaviors? Tests of an implicit assumption and expanded model. Human Relations, 53(3), 359-386. DOI:10.1177/0018726700533004

Valle, M., \& Witt, L.A. (2001). The moderating effect of teamwork perceptions on the organizational politics-job satisfaction relationship. The Journal of Social Psychology, 141(3), 379-388. DOI: 10.1080/00224540109600559 
Van Saane, N., Sluiter, J.K., Verbeek, J.H.A.M., \& Frings-Dresen, M.H.W. (2003). Reliability and validity of instruments measuring job satisfaction-a systematic review. Occupational Medicine, 53(3), 191-200. DOI:10.1093/occmed/kqg038.

Vigoda-Gadot, E., \& Kapun, D. (2005). Perceptions of politics and perceived performance in public and private organizations: A test of one model across two sectors. Policy and Politics, 33(2), 251-276.

Vredenburgh, D., \& Shea-Van Fossen, R. (2010). Human nature, organizational politics, and human resource development. Human Resource Development Review, 9(1), 26-47.

Weiss, H.M. (2002). Deconstructing job satisfaction: separating evaluations, beliefs and affective experiences. Human Resource Management Review, 12(2), 173-194. DOI: 10.1016/S1053-4822(02)00045-1

Witt, L.A., \& Beokermen, M.N. (1991), Satisfaction with initial work assignment and organisational commitment. Journal of Applied Social Psychology, 21 (21), 1783-1792.

Zanzi, A., \& O’Neill, R.M. (2001). Sanctioned versus non-sanctioned political tactics. Journal of Managerial Issues, 13(2), 245-262.

Zibenberg, A. (2017). Perceptions of Organizational Politics: A Cross-cultural Perspective. Global Business Review, 18(4), 849-860, DOI:0.1177/0972150917692211 